Original Research Paper

\title{
Predictive Dynamics of Channel Pattern Changing Trends at Arial Khan River (1977-2018), Bangladesh
}

\author{
${ }^{1}$ Rathindra Nath Biswas, ${ }^{2}$ Md. Juel Mia and ${ }^{3}$ M. Nazrul Islam \\ ${ }^{1}$ Center for Environmental and Geographic Information Services (CEGIS), Dhaka-1212, Bangladesh \\ ${ }^{2}$ Institute of Disaster Management and Vulnerability Studies, University of Dhaka, Dhaka-1000, Bangladesh \\ ${ }^{3}$ Department of Geography and Environment, Jahangirnagar University, Savar, Dhaka-1342, Bangladesh
}

Article history

Received: 08-08-2018

Revised: 29-09-2018

Accepted: 15-11-2018

Corresponding Author: Rathindra Nath Biswas Center for Environmental and Geographic Information Services (CEGIS), Dhaka-1212, Bangladesh

Email: rathingeoju39@gmail.com

\begin{abstract}
Arial Khan River is right bank distributary of Ganges-Padma River systems flowing southwest region of Bangladesh. It is morphologically very dynamic meandering river: where the deltabuilding process is more active than other distributaries of GangesBrahmaputra-Meghna (GBM) River basin. This study analyzes, morphological variables- channel length, valley length, channel area and channel patterns of Arial Khan River. A major portion of this river divided into 8 reaches from starting point Faridpur to outlet point Barisal district in order to measure channel pattern changing trends. For the proper accomplishment of the findings section of this research, time-series satellite images (Landsat MMS, Landsat TM, Landsat ETM ${ }^{+}$ and OLI) of the year 1977 to 2018 has been taken for delineation of the morphological parameters using GIS and RS techniques. In this research, sinuosity ratio index technique has been applied to analyze the morphological parameter- channel pattern and its changing trends. From the satellite images analysis results over time span, it is observed that significant morphological changes have been occurred in the river length, valley length, river area and its channel patterns. Likewise, the hydro-morphological parameters of this river (e.g., discharge, flow velocity, the river depth, width and pattern) also significantly changed due to combined massive sediment deposition from Ganges-Padma and Brahmaputra-Jamuna River systems. These hydro-morphological changes increased flood hazard vulnerability, bank erosion and sand carpeting; which badly impacted on ecological diversity, agriculture system, rural settlements and transportation networks.
\end{abstract}

Keywords: Channel Dynamics, Sinuosity Ratio (SR), Fluvial Environment, Meandering River

\section{Introduction}

Arial Khan is a perennial meandering river of Bangladesh. The hydro-morphological characteristics of this river are very dynamic in nature (Winkley et al., 1994). Due to dynamic behavior of the river, various fluvial hazards observed during recent decay. These fluvial hazards drastically damage agriculture crops, rural socio-economic infrastructures and waterway navigation systems (Islam, 2000). Moreover, hydromorphodynamic manners of this river made scarcity of water for irrigation in the agriculture crops land; extinction of aquatic fish resources, erosion of valuable flood plain and soil (Akter et al., 2013). At the same time, regular morphological response of this river creating human migration, making people landless and finally accelerating extreme of poverty.

Arial Khan River morphological configuration is almost influenced by hydrological variables of the parent river Ganges-Padma. After the construction of Farakka Barrage in 1975, a remarkable variations happened in hydrological parameters such as 
discharges, water label, flow velocity of this river (Dewan et al., 2017) and these hydraulic phenomena significantly controlled geometry, configuration and morphological aspects of its right bank distributary Arial Khan River. Discharge and flow velocity of Arial Khan River are significantly declined which is contributing to raise siltation on river bed and develop bar; and its main channel is converted to braiding status from meandering. Hydrological variables like discharge, water velocity and water level are declined in dry season; raising siltation on river bed, decreasing depthness and accelerating in bar development. On the other hand, in rainy season when above mentioned hydrological variables are raised, lateral erosion is happened increasingly than vertical erosion; and intensifying river bank movement and flood plain erosion.

Alluvial Arial Khan River management strategies becomes difficult because of bar development, bank shifting, meander belt development, regular loop cut and changes of channel pattern. Government takes various initiatives to protect river side resources from the vulnerability of river bank erosion and flood. The river bank erosion and flood wash away community's property, settlements and their domestic cattle which make homeless and jobless (Bhuiyan et al., 2017).

Time series remote sensing satellite imageries interpretation provide better results in fluvial channel geometry extraction and evaluation of changing trends (Ophra et al., 2018). GIS overly techniques provide spatio-temporal dynamics of fluvial channel variables. Several studies had been carried out to investigate, evaluate and monitor historical changes of alluvial channel morphological variables using Landsat remote sensing imageries in major's river of Bangladesh (Sarker et al., 2014; Islam et al., 2017). In-depth interview and focus group discussion from the river side rural community delivered the impacts of morphological response and fluvial hazards of Arial Khan River. This study applied taking photographs approach to examine morphological responses, current management strategies and barriers to hydrological variables of the river.

In this study, the objectives are to quantify the morphological variables; assess spatio-temporal changing trends of channel patterns using sinuosity index; and investigates impacts of hydro-morphological hazards on Arial Khan River Basin community. This study investigates how morphological variables changing, raising fluvial hazards and impacts on livelihoods patterns of river side community. The aim of this research is to assess fluvial geomorphological aspects and hydromorphological hazards of the alluvial Arial Khan River; and to suggest management strategies for hydrological regime of the study area. This research will help managing water resources, reducing disaster risk and developing agriculture systems of the study site.

\section{Materials and Methods}

To analyze changing trends of channel patterns of Arial Khan River, this study used satellite imageries collected from United States Geological survey (USGS). GIS and Remote sensing (ArcGIS 10.3 and ERDAS Imagine 2014) cartographic tools and techniques were used to interpret and delineate morphological variables and to produce maps. This research studied about $111 \mathrm{~km}$ of Arial Khan River which source point is Sadarpur in Faridpur district. The river is flowing through Madaripur-Shariatpur and reaching outlet point near Tentulia of Barishal district (Fig. 1). Landsat Satellite imageries of 1977 , 1988, 1991, 2000, 2010 and 2018 are examined for extraction of morphological variables such as stream length, valley length and river area. In this study, river were divided into eight reaches $(a-h)$ for examination of bend development direction, shifting nature and channel pattern changing trends (Fig. 2). These morphological variables were used to calculate channel pattern using the formula of Schumm (1963). The Sinuosity Ratio Index (SRI) was used for assigning channel pattern of Arial Khan River using the following equation (Schumm, 1963):

$S R I=\frac{L_{c}}{L_{v}}$

where, $L_{c}$ and $L_{V}$ denotes channel and valley length respectively. SRI denotes Sinuosity Ratio Index (SRI) which expresses the flowing condition for the prediction of channel pattern: Straight channel, when SRI is less than 1.05 ( $\mathrm{SRI}<1.05)$; sinuous channel, when SRI is between 1.05 and $1.5(1.05 \leq \mathrm{SRI}<1.5)$ and meandering channel, when SRI is more than 1.5 (SRI $>1.5$ ) (Leopold and Wolman, 1960; Schumm, 1963; Yeasmin and Islam, 2011).

In-Depth Interviews (IDI), Focus Group Discussions (FGD) and Taking photographs approaches were applied to collect primary data. For in-depth analysis, this study interviewed fisherman, farmer, small businessman, boat driver, students who are the inhabitants of Arial Khan river influence zone. For more understanding of the morphological responses of the river, this study also conducted Focus Group Discussions (FGD). Taking photographs option were used for the field evidence. 


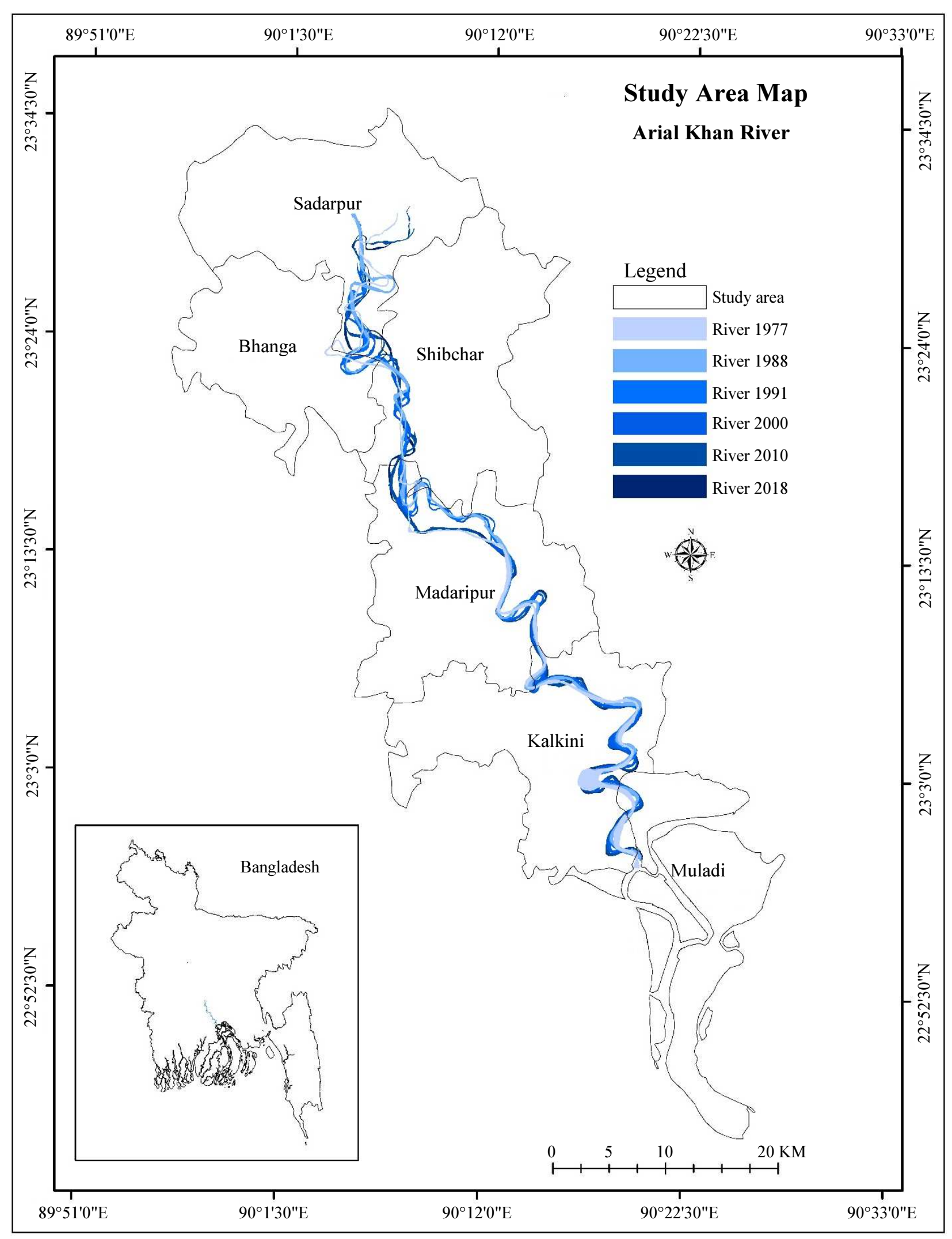

Fig. 1: Location of Arial Khan River in the study area 


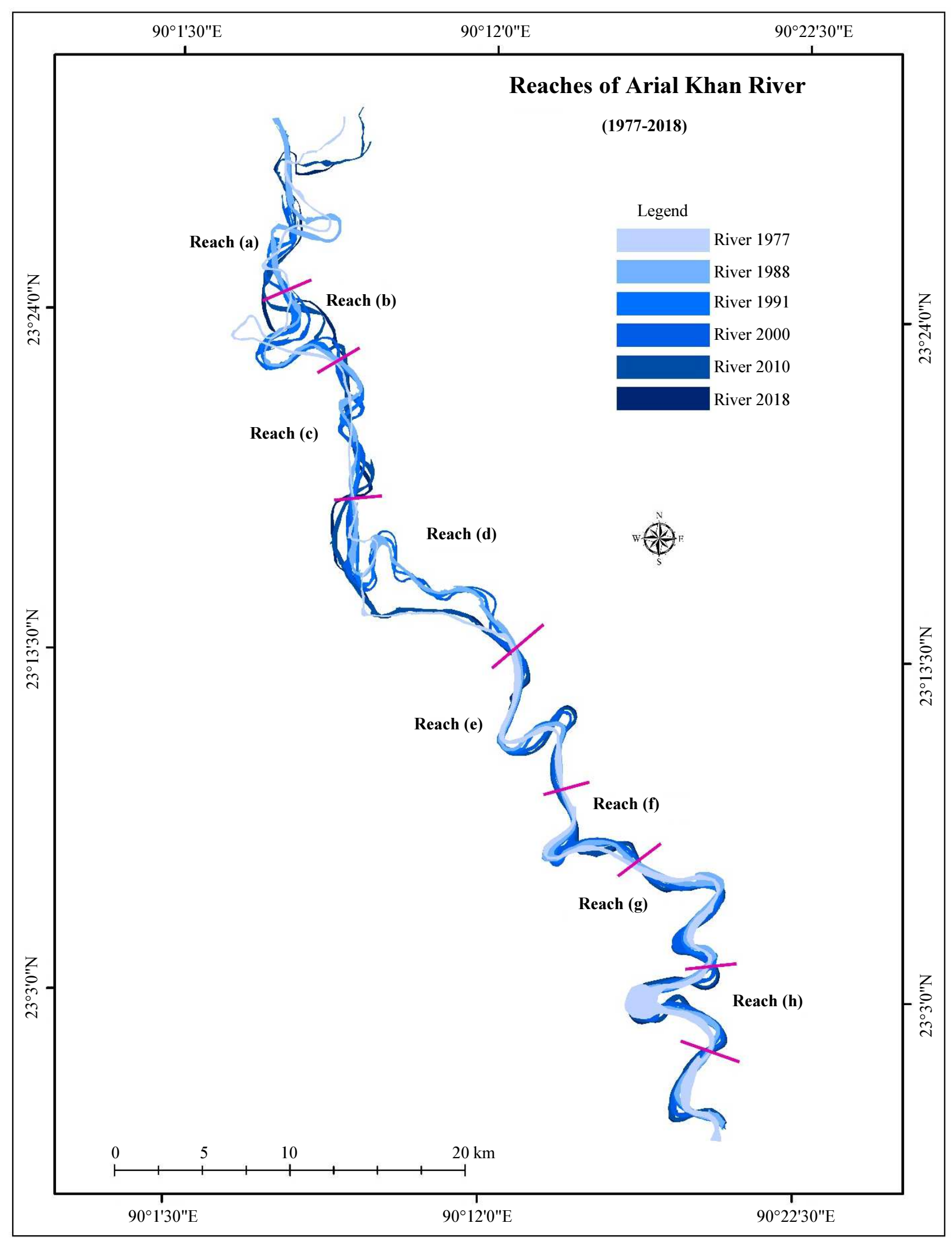

Fig. 2: Channel geometry and reaches of Arial Khan River 


\section{Results and Discussion}

\section{Channel Length and Valley Length Changing Trends}

Arial Khan River is originated from Ganges-Padma River. Starting point of the river was Rajbari district in 1940s. At present, its main source is located in Faridpur district. In recent years, most of the parts of this river merge with Padma River due to right bank erosion of Padma. It results variation in length, valley length and sinuosity ratio (Fig. 3). From Table 1, the study reveals that the length of Arial Khan River in the study area is increased $105.58 \mathrm{~km}$ in 1977 to $110.85 \mathrm{~km}$ in 2018 . On the other hand, the valley length was decreased $62.0789 \mathrm{~km}$ in 1977 to $59.0795 \mathrm{~km}$ in 2018 .

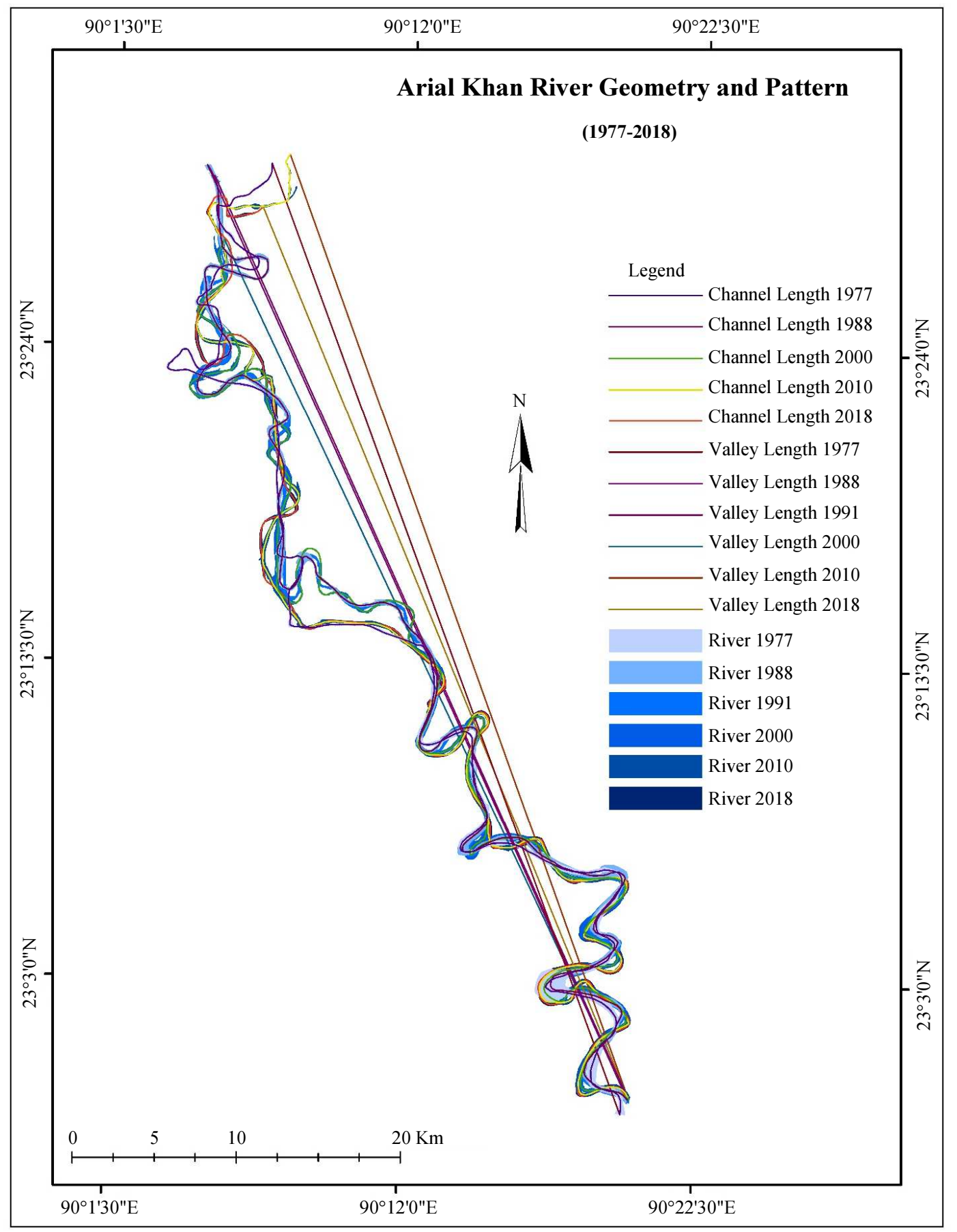

Fig. 3: Channel length, valley length and sinuosity ratio of Arial Khan River (1977-2018) 

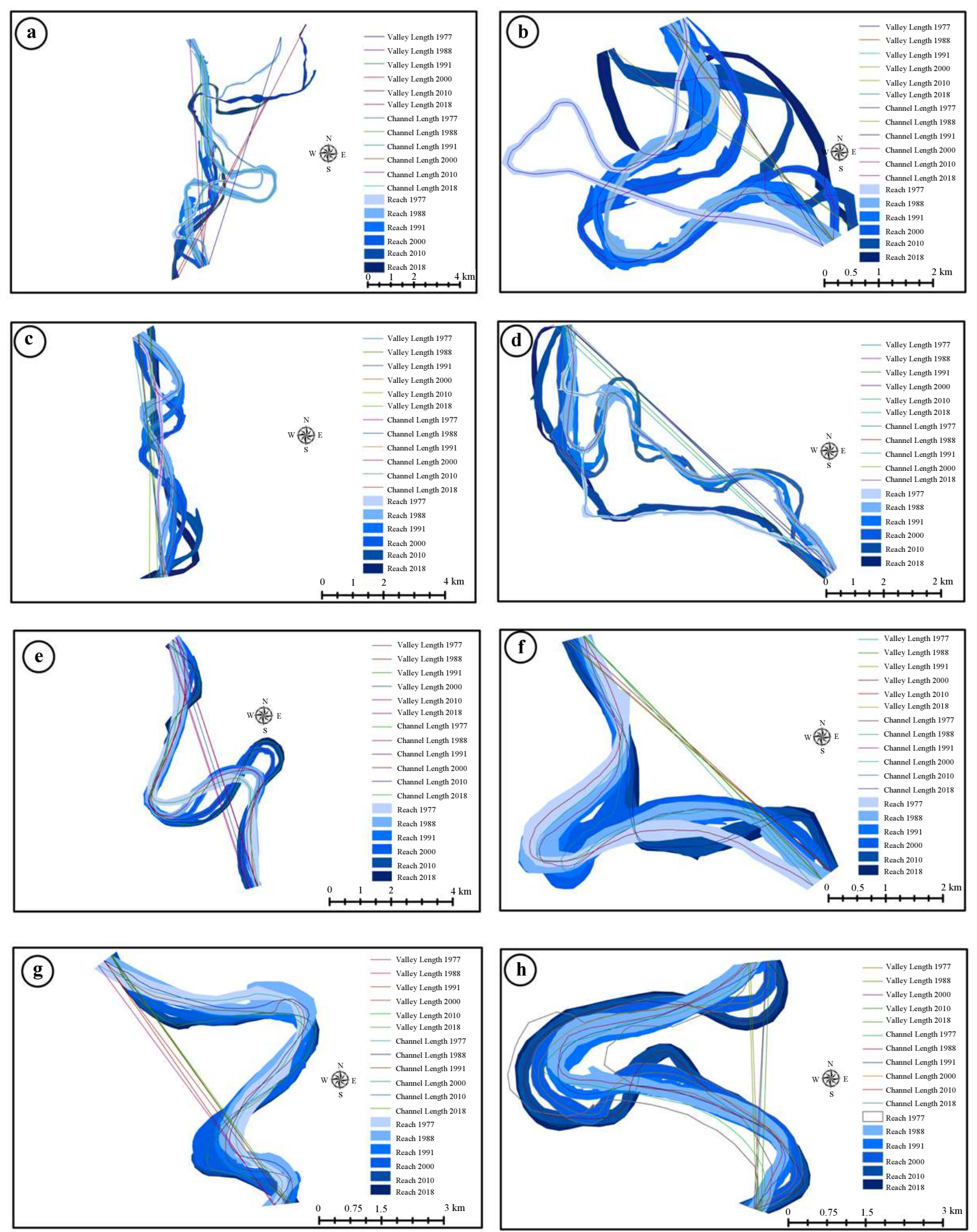

Fig. 4: Map showing channel patterns of Arial Khan River reaches ( $a$ - $h$ ) during 1977-2018 


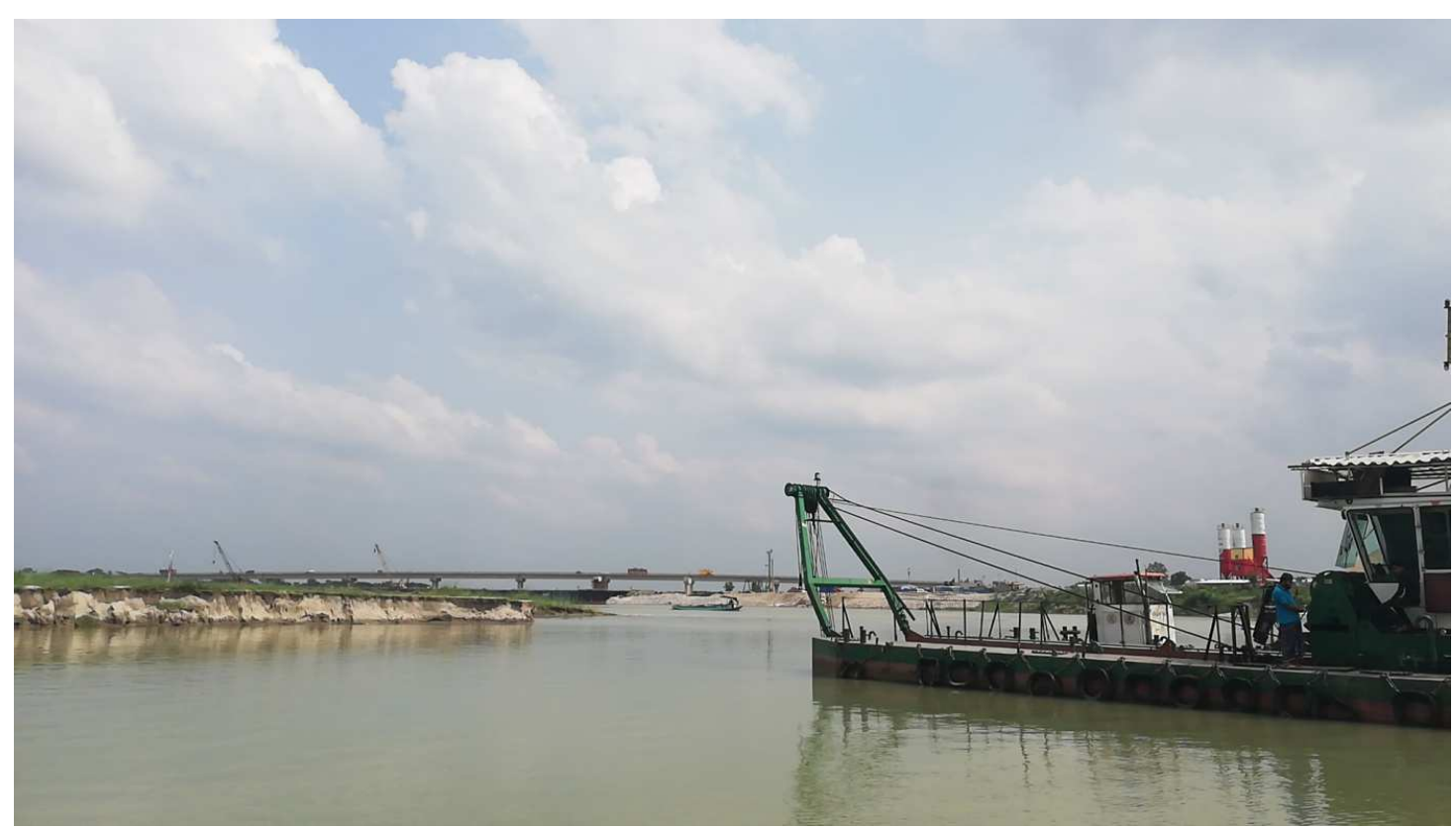

(a)

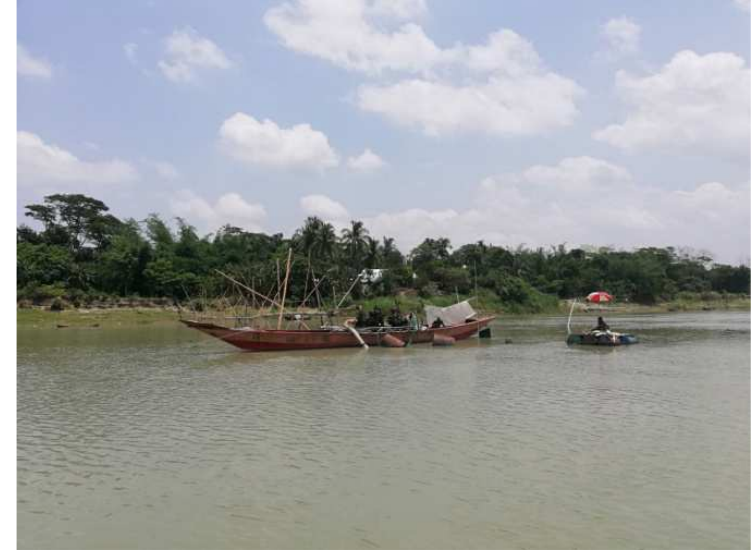

(b)

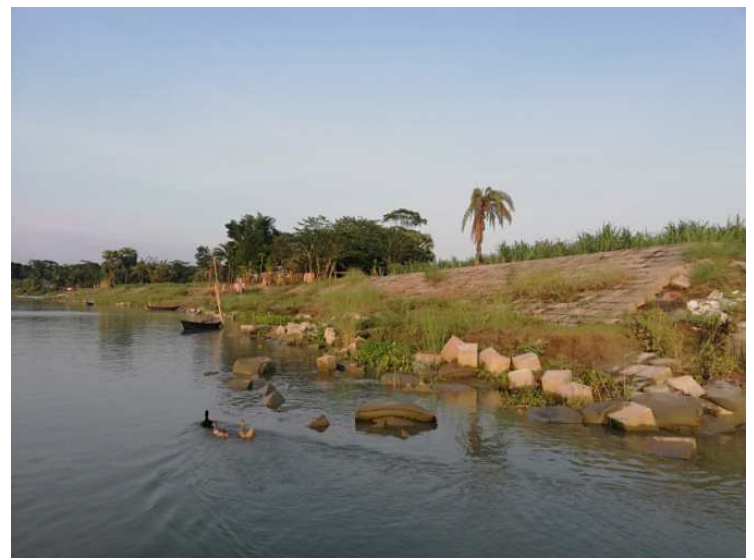

(d)

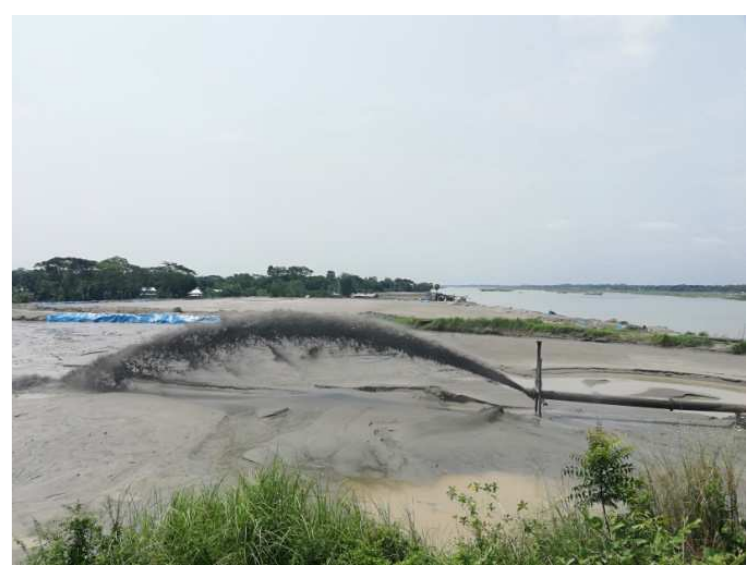

(c)

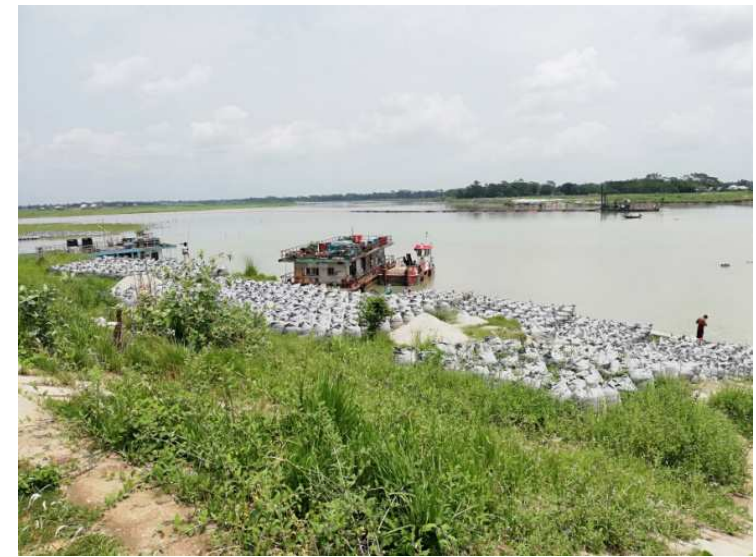

(e)

Fig. 5: Barrier and river management strategies; (a) Construction of Haji Shariaullah bridge over Arial Khan river, (b) Sand dredging from river for business purposes, (c) River aggression through dredging, (d) Embankment construction to protect river bank and (e) Storage of Geo-textile bags for use 
Table 1: Sinuosity measurement of Arial Khan River during the study period 1977-2018

\begin{tabular}{|c|c|c|c|c|c|}
\hline Year & $\begin{array}{l}\text { River area } \\
\text { (sq.km) }\end{array}$ & $\begin{array}{l}\text { Channel } \\
\text { length }(\mathrm{Km})\end{array}$ & $\begin{array}{l}\text { Valley } \\
\text { length }(\mathrm{km})\end{array}$ & $\begin{array}{l}\text { Sinuosity } \\
\text { Ratio (S.R) }\end{array}$ & $\begin{array}{l}\text { Channel } \\
\text { pattern }\end{array}$ \\
\hline 1977 & 25.5767 & 105.5860 & 62.0789 & 1.701 & Meandering \\
\hline 1988 & 32.1917 & 106.5950 & 62.8188 & 1.697 & Meandering \\
\hline 1991 & 31.7054 & 103.6600 & 62.0131 & 1.671 & Meandering \\
\hline 2000 & 30.5582 & 110.2930 & 58.2496 & 1.893 & Meandering \\
\hline 2010 & 26.7385 & 109.6430 & 61.3991 & 1.786 & Meandering \\
\hline 2018 & 22.9909 & 110.8507 & 59.0795 & 1.876 & Meandering \\
\hline
\end{tabular}

Table 2: Morphological parameter changing trends of Arial Khan River during 1977-2018

\begin{tabular}{|c|c|c|c|c|c|}
\hline \multirow[b]{2}{*}{ Parameter } & \multicolumn{5}{|l|}{ Period } \\
\hline & $1977-1988$ & 1988-1991 & $1991-2000$ & $2000-2010$ & $2010-2018$ \\
\hline River length in $(\mathrm{km})$ & 1.0090 & -2.9350 & 6.6330 & -0.6500 & -1.2077 \\
\hline Valley length $(\mathrm{km})$ & 0.7399 & -0.8057 & -3.7614 & 3.1495 & 2.3196 \\
\hline Sinuosity Ratio (S.R) & -0.0038 & -0.0260 & 0.2220 & -0.1070 & -0.0850 \\
\hline
\end{tabular}

Note: Minus sign indicates decrease and a positive sign indicates the increase

This results indicated that channel pattern changing trends is dynamic. But it varies also on its reaches during the study period. In this study, there is an irregular change noticeable in river length of Arial Khan reaches (a-h) since 1977 to 2018 (Fig. 4). Regular inundation of this basin with monsoon rainfall and flood water, accumulation of high amount of sedimentation from Ganges-Padma and Brahmaputra river systems, regular loop cuts of its channel, channel shifting and bank erosion, agricultural practice in river valley during the dry season and human intervention (e.g., settlement construction, illegal river dredging, bridge construction) on river bank (Fig. 5) are responsible for this variation of change. As a results, the channel pattern changing trends of this river is dynamics.

The results also revealed that among the reaches of Arial Khan River reach $(h)$ channel length is continuously increased from $10.51 \mathrm{~km}$ in 1977 to 15.98 $\mathrm{km}$ in 2018 (Table 3) which is located in Meghna estuary in Barisal district where delta forming process is more active. Channel length was regularly increased in the reaches of $(e)$ and $(h)$; decreased channel length in reaches of $(a)$ and $(b)$ during the study period. Measuring valley length, the study found that valley length was little change during the study period 1977 to 2018. This results revealed that increased meander bends and loop cuts of the channel are the main reason for it. Particularly reach $(a)$ is located near the confluence zone of Ganges-Padma and BrahmaputraJamuna River that's why irregular channel length along with valley length was decreased due to huge sedimentation in the river mouth.

\section{Sinuosity Ratio Changing Trends}

The present use of empirical study is to predict channel pattern changing trends of the Arial Khan
River mainly related to sinuosity ratio measurement. Sinuosity ratio is measured for understanding the present condition of Arial Khan River. Sinuosity measurement results of the Arial khan river are summarized in Table 1 . The results revealed that sinuosity ratio increased irregularly over the time. The change of sinuosity ratio (0.222) between 1991 and 2000 was particularly high (Table 2 ). It should be noted that sinuosity ratio was not continuous, it was dynamics during the study period.

The variations of sinuosity ratio among the reaches of Arial Khan River were observed during the study period of 1977-2018. Sinuosity measurement result of Arial Khan River reaches are summarized in Table 3. The results revealed that sinuosity ratio of the reach (a) decreased from 1.66 in 1977 to 1.58 in 2018 . The sinuosity ratio of reach $(b)$ is decreased over time. In 2000 , sinuosity ratio was high which indicates higher meandering status and the change of sinuosity ratio between 1991 and 2010 (0.48) was also particularly high (Table 4). But the outcome results indicated that sinuosity ratio of reach (c) was continuously increased from 1.03 in 1977 to 1.22 in 2000 . The changing trend of this reach was straight to sinuous. The change of sinuosity between 1977 and 1988 (0.146) was high. Reach $(d)$ sinuosity measurement results revealed that it has remained steady at a value between 1.40 and 1.42 from the 1977 to 1988 , but then increased rapidly, attaining a value approaching 1.82 in 2000 . In Reach $(e)$, the results unveiled that the sinuosity ratio rapidly increased from 1.42 in 1977 to 2.05 in 2018 . However, in 1977 it was very close to 1.5 which indicates meandering river. After 1977, the rate of sinuosity ratio was raised. The analysis outcome showed that sinuosity ratio of reach $(f)$ was not 
continuous, it was dynamics trends from meandering to sinuous condition over time 1977 to 2018 . The empirical results of reach $(g)$ shown that sinuosity ratio irregularly increased over the time. On the hand, it was remained steady at a value of 1.63 from 1988 to 1991, but then increased irregularly, attaining a value approaching 1.70 in 2018. However, the highly dynamic nature of this reach sinuosity ratio more change occurred between 1977 and 1988 which was 0.105 (Table 4$)$. The results of reach $(h)$ demonstrated that sinuosity ratio changing trends was continuously increased after 1977 up to 2018.

Table 3: Measurement of sinuosity ratio of Arial Khan River reaches during the study period 1977-2018

\begin{tabular}{|c|c|c|c|c|c|c|}
\hline Year & Reach & $\begin{array}{l}\text { Area in } \\
(\mathrm{sq} . \mathrm{km})\end{array}$ & $\begin{array}{l}\text { Channel } \\
\text { length }(\mathrm{km})\end{array}$ & $\begin{array}{l}\text { Valley } \\
\text { length }(\mathrm{km})\end{array}$ & $\begin{array}{l}\text { Sinuosity } \\
\text { Ratio (S.R) } \\
\end{array}$ & $\begin{array}{l}\text { Channel } \\
\text { pattern }\end{array}$ \\
\hline \multirow[t]{8}{*}{1977} & Reach- $a$ & 2.27 & 17.08 & 10.31 & 1.66 & Meandering \\
\hline & Reach- $b$ & 1.75 & 12.83 & 4.91 & 2.61 & Meandering \\
\hline & Reach-c & 1.06 & 8.04 & 7.84 & 1.03 & Straight \\
\hline & Reach- $d$ & 2.50 & 17.58 & 12.55 & 1.40 & Sinuous \\
\hline & Reach-e & 3.48 & 11.96 & 8.42 & 1.42 & Sinuous \\
\hline & Reach- $f$ & 2.49 & 9.94 & 5.90 & 1.68 & Meandering \\
\hline & Reach-g & 3.29 & 10.96 & 7.17 & 1.53 & Meandering \\
\hline & Reach- $h$ & 5.91 & 10.51 & 4.80 & 2.19 & Meandering \\
\hline \multirow[t]{8}{*}{1988} & Reach- $a$ & 4.70 & 16.77 & 9.85 & 1.70 & Meandering \\
\hline & Reach- $b$ & 2.07 & 10.08 & 4.98 & 2.03 & Meandering \\
\hline & Reach-c & 2.21 & 9.28 & 7.92 & 1.17 & Sinuous \\
\hline & Reach- $d$ & 4.74 & 17.96 & 12.63 & 1.42 & Sinuous \\
\hline & Reach-e & 3.92 & 13.51 & 8.48 & 1.59 & Meandering \\
\hline & Reach- $f$ & 3.43 & 10.25 & 5.93 & 1.73 & Meandering \\
\hline & Reach- $g$ & 4.89 & 11.69 & 7.16 & 1.63 & Meandering \\
\hline & Reach- $h$ & 3.78 & 10.58 & 4.78 & 2.21 & Meandering \\
\hline \multirow[t]{8}{*}{1991} & Reach- $a$ & 3.02 & 10.45 & 9.16 & 1.14 & Sinuous \\
\hline & Reach- $b$ & 3.45 & 10.41 & 4.97 & 2.10 & Meandering \\
\hline & Reach-c & 2.59 & 9.29 & 7.91 & 1.18 & Sinuous \\
\hline & Reach- $d$ & 4.65 & 19.67 & 12.65 & 1.55 & Meandering \\
\hline & Reach-e & 3.56 & 13.98 & 8.48 & 1.65 & Meandering \\
\hline & Reach- $f$ & 3.20 & 10.27 & 5.94 & 1.73 & Meandering \\
\hline & Reach- $g$ & 4.66 & 11.93 & 7.31 & 1.63 & Meandering \\
\hline & Reach- $h$ & 4.10 & 11.06 & 4.80 & 2.30 & Meandering \\
\hline \multirow[t]{8}{*}{2000} & Reach- $a$ & 1.61 & 6.69 & 5.33 & 1.30 & Sinuous \\
\hline & Reach- $b$ & 2.80 & 12.89 & 5.00 & 2.58 & Meandering \\
\hline & Reach-c & 2.65 & 9.63 & 7.93 & 1.22 & Sinuous \\
\hline & Reach- $d$ & 4.72 & 22.89 & 12.61 & 1.82 & Meandering \\
\hline & Reach-e & 4.32 & 15.60 & 8.42 & 1.85 & Meandering \\
\hline & Reach- $f$ & 3.62 & 10.08 & 6.06 & 1.66 & Meandering \\
\hline & Reach-g & 4.20 & 11.91 & 7.34 & 1.62 & Meandering \\
\hline & Reach- $h$ & 3.98 & 13.34 & 4.81 & 2.78 & Meandering \\
\hline \multirow[t]{12}{*}{2010} & Reach- $a$ & 2.35 & 16.51 & 12.27 & 1.35 & Sinuous \\
\hline & Reach- $b$ & 1.75 & 7.55 & 5.54 & 1.36 & Sinuous \\
\hline & Reach-c & 2.26 & 9.18 & 8.12 & 1.13 & Sinuous \\
\hline & Reach- $d$ & 3.99 & 16.05 & 12.72 & 1.26 & Sinuous \\
\hline & Reach-e & 3.77 & 16.75 & 8.34 & 2.01 & Meandering \\
\hline & Reach- $f$ & 1.99 & 7.86 & 6.12 & 1.28 & Sinuous \\
\hline & Reach- $g$ & 3.81 & 12.36 & 7.34 & 1.68 & Meandering \\
\hline & Reach- $h$ & 4.18 & 15.47 & 4.82 & 3.21 & Meandering \\
\hline & Reach- $a$ & 1.67 & 13.90 & 8.78 & 1.58 & Meandering \\
\hline & Reach- $b$ & 1.40 & 9.08 & 5.66 & 1.60 & Meandering \\
\hline & Reach-c & 2.13 & 9.48 & 8.18 & 1.16 & Sinuous \\
\hline & Reach- $d$ & 2.55 & 16.48 & 12.89 & 1.28 & Sinuous \\
\hline \multirow[t]{4}{*}{2018} & Reach-e & 3.23 & 17.07 & 8.33 & 2.05 & Meandering \\
\hline & Reach- $f$ & 1.93 & 7.97 & 6.13 & 1.30 & Sinuous \\
\hline & Reach-g & 3.78 & 12.53 & 7.37 & 1.70 & Meandering \\
\hline & Reach- $h$ & 3.98 & 15.98 & 4.88 & 3.27 & Meandering \\
\hline
\end{tabular}


Table 4: Changing trends of channel length, valley length and sinuosity ratio of Arial Khan River riches during the study period 1977-2018

\begin{tabular}{|c|c|c|c|c|c|c|}
\hline \multirow[b]{2}{*}{ Parameter } & \multirow[b]{2}{*}{ Reach } & \multicolumn{5}{|l|}{ Period } \\
\hline & & $1977-1988$ & 1988-1991 & $1991-2000$ & $2000-2010$ & $2010-2018$ \\
\hline \multirow[t]{8}{*}{ Channel length } & Reach- $a$ & -0.305 & -6.319 & -3.760 & 9.818 & 2.61 \\
\hline & Reach- $b$ & -2.745 & 0.333 & 2.473 & -5.339 & -1.53 \\
\hline & Reach-c & 1.235 & 0.013 & 0.341 & -0.455 & -0.30 \\
\hline & Reach-d & 0.389 & 1.701 & 3.225 & -6.839 & -0.43 \\
\hline & Reach-e & 1.546 & 0.477 & 1.618 & 1.145 & -0.32 \\
\hline & Reach- $f$ & 0.319 & 0.018 & -0.194 & -2.221 & -0.11 \\
\hline & Reach- $g$ & 0.736 & 0.234 & -0.018 & 0.450 & -0.17 \\
\hline & Reach- $h$ & 0.073 & 0.481 & 2.274 & 2.136 & -0.51 \\
\hline \multirow[t]{8}{*}{ Valley length } & Reach- $a$ & -0.458 & -0.692 & -3.828 & 6.934 & 3.49 \\
\hline & Reach- $b$ & 0.063 & -0.007 & 0.035 & 0.538 & -0.12 \\
\hline & Reach-c & 0.081 & -0.011 & 0.017 & 0.192 & -0.06 \\
\hline & Reach-d & 0.072 & 0.025 & -0.037 & 0.105 & -0.17 \\
\hline & Reach-e & 0.056 & -0.002 & -0.057 & -0.077 & 0.01 \\
\hline & Reach- $f$ & 0.028 & 0.007 & 0.120 & 0.061 & -0.01 \\
\hline & Reach-g & -0.011 & 0.148 & 0.029 & 0.000 & -0.03 \\
\hline & Reach- $h$ & -0.021 & 0.022 & 0.002 & 0.012 & -0.06 \\
\hline \multirow[t]{8}{*}{ Sinuosity ratio } & Reach- $a$ & 0.046 & -0.561 & 0.157 & 0.048 & -0.23 \\
\hline & Reach- $b$ & -0.584 & 0.070 & 0.480 & -1.214 & -0.24 \\
\hline & Reach-c & 0.146 & 0.003 & 0.041 & -0.085 & -0.03 \\
\hline & Reach-d & 0.023 & 0.131 & 0.261 & -0.553 & -0.02 \\
\hline & Reach-e & 0.173 & 0.056 & 0.204 & 0.155 & -0.04 \\
\hline & Reach- $f$ & 0.046 & 0.000 & -0.065 & -0.380 & -0.02 \\
\hline & Reach-g & 0.105 & -0.001 & -0.009 & 0.061 & -0.02 \\
\hline & Reach- $h$ & 0.026 & 0.090 & 0.472 & 0.436 & -0.06 \\
\hline
\end{tabular}

\section{River Area Changing Trends}

Arial Khan River is a narrowest meandering channel. At present, its area is 22.99 sq. $\mathrm{km}$ and average area is $28.29 \mathrm{sq}$. $\mathrm{km}$ during the study period (Table 1). Variation was observed in river area during the study period from 1977 to 2018 . In this study, the results disclosed the change of river area between 1977 and 1988 (6.615) (Table 2); was particularly high because of the high magnitude of flood occurred in 1988 which was inundated most of the river basin. After 1988, the rate of the river area was declined. This results also indicated that huge sediment deposition impacts on river flow as it creates the bar (both point bar and attached bar). Because of the creation of bars in the middle of the river; velocity and depth of the river area decreased and found lateral erosion of the river. For that reason, the total river area varies over the time. Results also shown that area of Arial Khan River reaches was not stable, its changing nature was dynamic.

\section{People's Perception on River Bank Erosion, Impacts and Management Strategies}

This study conducted In-depth Interview (IDI) of river side community. Local people described their perceived knowledge, livelihood and life dynamics. Farmers and marginal people are suffering for river bank erosion. Agriculture land and structural development are vulnerable along the river side (Fig. 6a to 6e). A farmer from Bhatirchar village of Madaripur district, commented that:

Last year (2017), within three hours river washed away my one and half bigha (0.24 hectares) agriculture land where I produced different crops such as rice, sugarcane, jute and pulses. Now, I am afraid of my home which is much closed to the river. If the government doesn't take immediate steps to protect river bank, our home will go into river. What will I do, only God knows!

River bank erosion impacts on people's occupation and their livelihood. Not only that, Arial Khan River bank erosion creates psychological pressure. Some people affected several times by river bank erosion. Two affected people from Shibchar sub-district of Madaripur, stated that:

I have been the victim of river erosion for eight times. Burning home seven times is equals to loosing home into river. I used to farm paddy earlier, but at present it doesn't give any yield because of erosion. What should I do now! Almost all of my agriculture lands are demolished so, I have moved away from agriculture activities. 
So far, I faced river erosion for six times. I build, river erode. People of our locality faced river erosion at least two times in

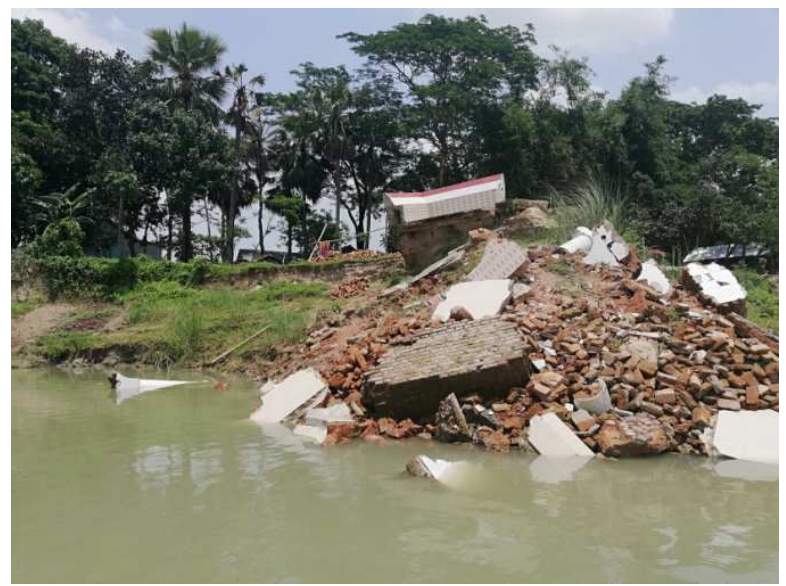

(a)

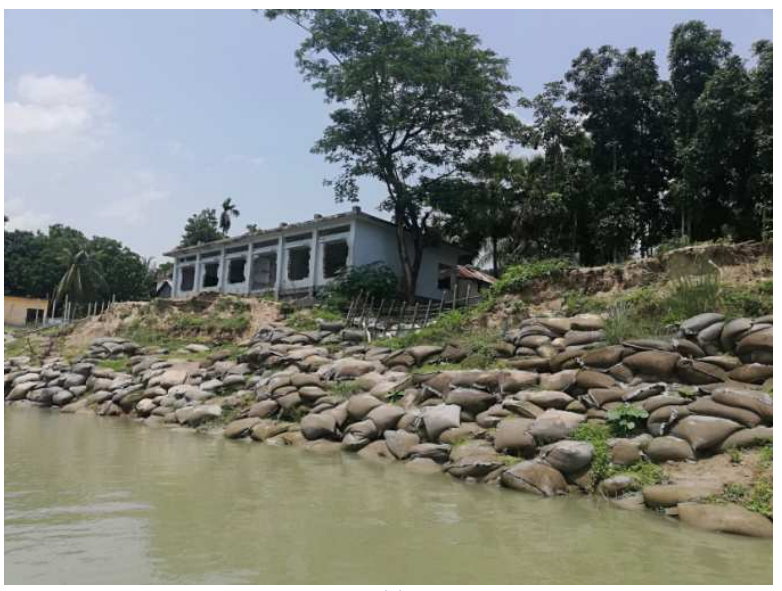

(c)

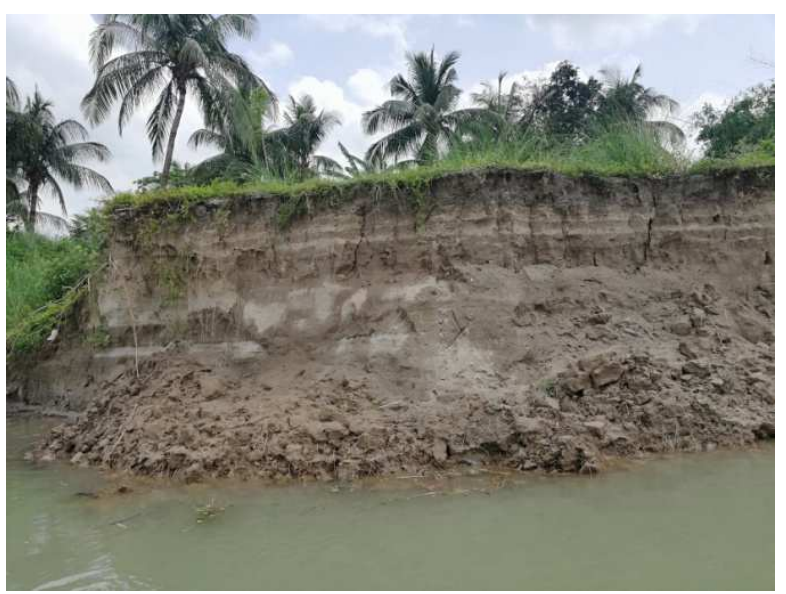

(e) their lives. Those who lost their lands into river, they cultivate other's land in exchange of money.

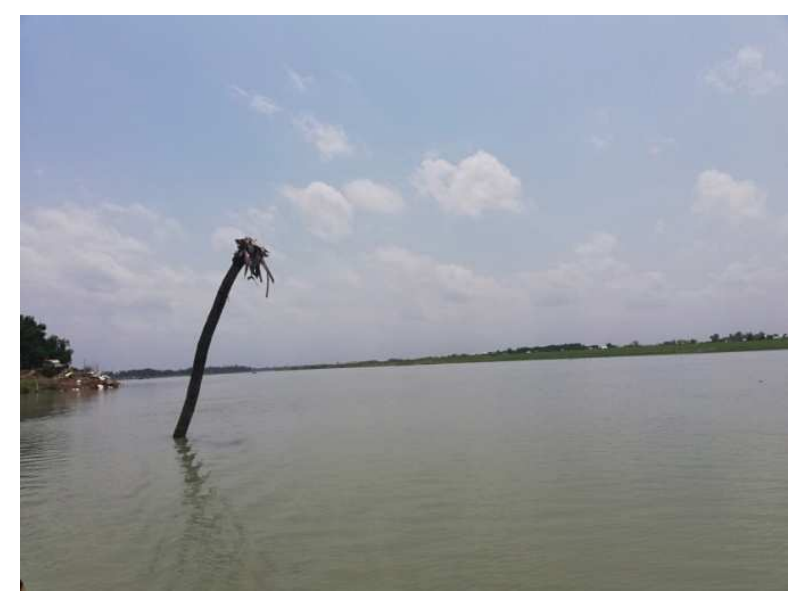

(b)

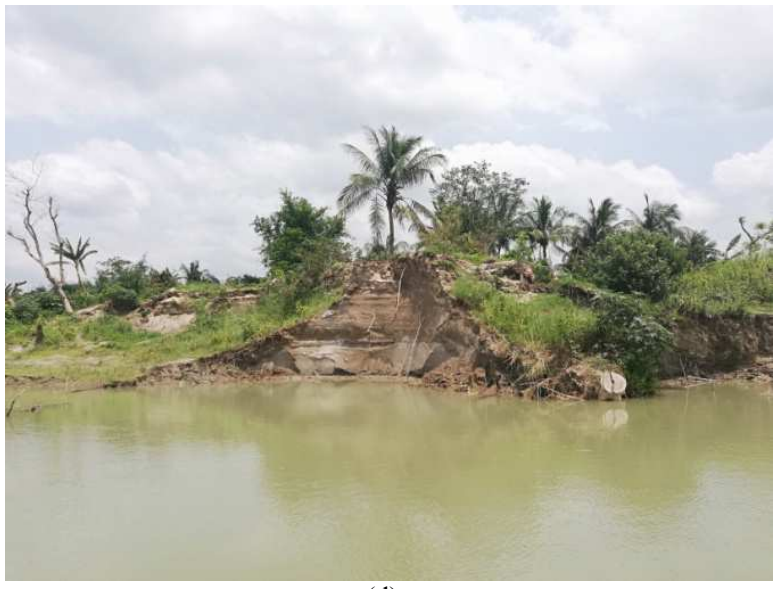

(d)

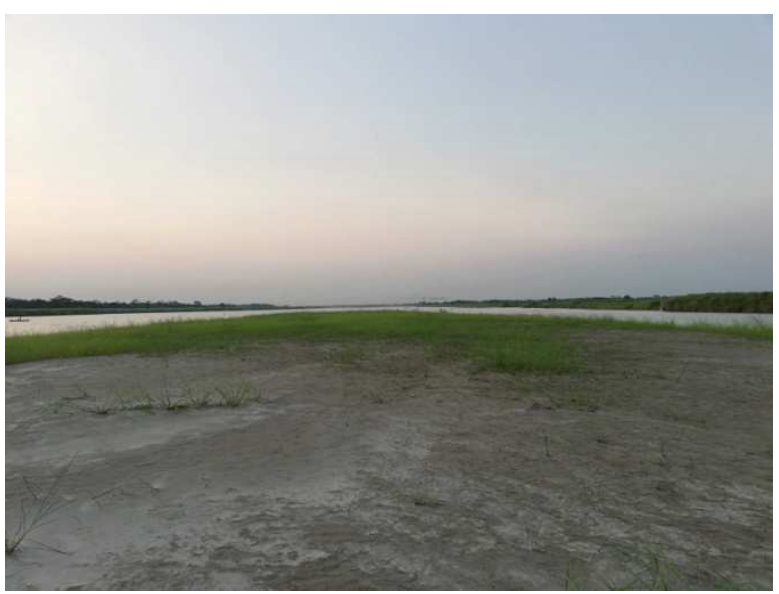

(f)

Fig. 6: Morphological responses of Arial Khan River; (a) Structural destruction by river bank erosion, (b) Settlement with homesteade vegetation washed away into river, (c) Educational institution are in risk, (d) Vulnerable settlement and homestead vegetation, (e) Mainland floodplain and soil erosion and f) Sandy barland development by sediment deposition 
Due to river bank erosion, people sometimes bound to migrate themselves from one place to another. When disappeared land awakened, people become dreamed again. Community people explained migration issues from their own way. A small businessman from Faridpur district commented that:

Erosion starts when rainy season comes. Erosion hits eighteen times in my life. The land has risen again which I lost earlier. We move after erosion and build house again. About 90 percent people shifted house within own locality for erosion. When anybody hits by erosion, neighbors comes to help.

Morphological changes of Arial Khan River impacts on navigability, aquatic fish resources and bar development (Fig. 6f). A young educated boy's from Utrail of Madaripur district mentioned the impacts of morphological changes by following statement:

\begin{abstract}
River navigability is falling. Once huge amount of fishes were found, now people are forced to farm fish for their livelihood. Currently Arial Khan River is flowing straight by splitting bar (charland) after the construction of Haji Shariatullah Bridge. Some victims of river erosion migrated themselves to cities including capital.
\end{abstract}

\section{Recommendation}

a) Illegal and unplanned dredging must be stopped; government can take steps of regular dredging

b) Riparian vegetation should initiate to protect human settlements, agriculture land and road networks from the risk of river bank erosion

c) Rehabilitation approaches, re-settlement and employment opportunities should be provided by Government and Non-government organizations to the river bank erosion affected people

d) Micro-credit banking sectors and Small-to-Medium Enterprise (SME) should provide money with little interest who are affected by river bank erosion for reconstruction of settlements and others

e) Embankment construction should be taken by Government along the river bank erosion vulnerable zone

f) Easily moveable house should be made instead of concrete housing patterns along river side area

\section{Conclusion}

Arial Khan River is a branch of Ganges-Padma River which channel patterns changing trends is dynamic. Channel pattern of the river is measured and analyzed by applying Sinuosity Ratio (SRI) equation formula given by Schumm (1963). In this equation formula the Sinuosity Ratio (SRI) more than 1.5 (SRI> 1.5) expresses meandering river channel and less than 1.5 $(\mathrm{SRI}<1.5)$ refers straight river channel. This research revealed that the length of the river in 1977, 1988, 1991, 2000, 2010 and 2018 followed by $105.586 \mathrm{~km}, 106.595$ $\mathrm{km}, 103.66 \mathrm{~km}, 110.293 \mathrm{~km}, 109.643 \mathrm{~km}$ and 110.851 $\mathrm{km}$, respectively and the sinuosity ratio represent 1.701 , $1.697,1.671,1.893,1.786$ and 1.876 , respectively. Since 1977 to 2018 major changes of Channel occurred in reach $h$. In 1977 sinuosity ratio of the reach was 2.19 , in 1988 sinuosity ratio was 2.21 , in 1991 sinuosity ratio was 2.30 , in 2000 sinuosity ratio was 2.78 , in 2010 sinuosity ratio was 3.21 and, in 2018 sinuosity ratio was 3.27. Little change has occurred in channel length at the reaches of $\mathrm{c}$ and $d$, regular increased was found at reaches $e$ and $h$ and length was decreased at reaches of $a$ and $b$. Overall, the Arial Khan River is becoming more meandering trend day by day. This research also recommended that highly scientific research is needed to analyze channel pattern changing trends dynamics by using geological, hydro-geomorphological and human intervention data for developing agricultural systems and ecosystem of the environment of this area.

\section{Acknowledgment}

Disaster Perception, a volunteer platform, helped us to conduct field observation and case study. We would like to recognize anonymous reviewers for giving valuable and critical comments.

\section{Author's Contributions}

Rathindra Nath Biswas: Designed research, analyzed data and wrote the manuscript.

Md. Juel Mia: Designed research, conducted field study and contributed in interpretation.

Md. Nazrul Islam: Supervised the study and revised the manuscript.

\section{Ethics}

Authors declared no ethical issues that may arise after the publication.

\section{References}

Akter, J., M.H. Sarker and P. Haque, 2013. Morphological processes and effective river erosion management: A case study of the Arial Khan River in Bangladesh. Proceedings of the 4th International Conference on Water and Flood Management, (WFM' 13), Dhaka, Bangladesh, pp: 263-274. 
Bhuiyan, M.A.H., S.D.U. Islam and G. Azam, 2017. Exploring impacts and livelihood vulnerability of riverbank erosion hazard among rural household along the river Padma of Bangladesh. Environ. Syst. Res., 6: 25-25. DOI: 10.1186/s40068-017-0102-9

Dewan, A., R. Corner, A. Saleem, M.M. Rahman and M.R. Haider et al., 2017. Assessing channel changes of the Ganges-Padma River system in Bangladesh using Landsat and hydrological data. Geomorphology, 276: 257-279.

DOI: 10.1016/j.geomorph.2016.10.017

Islam, M.N., 2000. Braiding and channel morphodynamics: the Brahmaputra-Jamuna river, Bangladesh. Doctoral dissertation, University of Hull.

Islam, R., M.N. Islam and M.N. Islam, 2017. Impacts of Bangabandhu Jamuna Multi-purpose Bridge on the dynamics of bar morphology at the Jamuna River in Bangladesh. Model. Earth Syst. Environ., 3: 903-925. DOI: $10.1007 / \mathrm{s} 40808-017-0342-8$

Leopold, L.B. and M.G. Wolman, 1960. River meanders. Geol. Soc. Am. Bull., 71: 769-793. DOI: 10.1130/0016-7606(1960)71[769:RM]2.0.CO;2
Ophra, S.J., S. Begum, R. Islam and M.N. Islam, 2018. Assessment of bank erosion and channel shifting of Padma River in Bangladesh using RS and GIS techniques. Spatial Inform. Res.

DOI: $10.1007 / \mathrm{s} 41324-018-0202-2$

Sarker, M.H., C.R. Thorne, M.N. Aktar and M.R. Ferdous, 2014. Morpho-dynamics of the Brahmaputra-Jamuna River, Bangladesh. Geomorphology, 215: 45-59. DOI: 10.1016/j.geomorph.2013.07.025

Schumm, S.A., 1963. Sinuosity of alluvial rivers on the Great Plains. Geol. Society Am. Bull., 74: 1089$1100 . \quad$ DOI: $10.1130 / 0016-$ 7606(1963)74[1089:SOAROT]2.0.CO;2

Winkley, B.R., E.J. Lesleighter and J.R. Cooney, 1994. Instability problems of the Arial Khan River, Bangladesh. The Variability of Large Alluvial Rivers, Schumm, S.A. and B.R. Winkley (Eds.), ASCE Press, New York, pp: 269-284.

Yeasmin, A. and M.N. Islam, 2011. Changing trends of channel pattern of the GangesPadmariver. Int. J. Geomat. Geosci., 2: 669-675. 